\title{
Candidaemia in a tertiary hospital in Nigeria
}

\begin{tabular}{|c|c|}
\hline $\begin{array}{l}\text { Authors: } \\
\text { Rita O. Oladel } \\
\text { Rashidi A. Bak } \\
\text { Michael A. Pe } \\
\text { Oyinlola O. Oc } \\
\text { Malcolm Rich }\end{array}$ & $\begin{array}{l}\text { are }^{1} \\
\text { rou }^{2} \\
\text { luyebo }^{3} \\
\text { ardson }^{4}\end{array}$ \\
\hline $\begin{array}{l}\text { Affiliations: } \\
{ }^{1} \text { Department } \\
\text { Microbiology } \\
\text { Parasitology, } \\
\text { College Hospit }\end{array}$ & $\begin{array}{l}\text { f Medical } \\
\text { and } \\
\text { Jniversity } \\
\text { al, Nigeria }\end{array}$ \\
\hline $\begin{array}{l}{ }^{2} \text { Department } \\
\text { Hammersmith } \\
\text { Imperial Colle }\end{array}$ & $\begin{array}{l}\text { f Microbiology, } \\
\text { Hospital, } \\
\text { ge, London }\end{array}$ \\
\hline $\begin{array}{l}{ }^{3} \text { Department } \\
\text { Microbiology, } \\
\text { Medicine, Uni } \\
\text { Lagos, Nigeria }\end{array}$ & $\begin{array}{l}\text { Codical } \\
\text { College of } \\
\text { versity of }\end{array}$ \\
\hline $\begin{array}{l}{ }^{4} \text { Mycology Ref } \\
\text { Laboratory, U } \\
\text { Manchester, L }\end{array}$ & $\begin{array}{l}\text { erence } \\
\text { iversity of } \\
\text { Inited Kingdom }\end{array}$ \\
\hline $\begin{array}{l}\text { Corresponden } \\
\text { Rita Oladele }\end{array}$ & e to: \\
\hline $\begin{array}{l}\text { Email: } \\
\text { drritaoladele }\end{array}$ & Dyahoo.com \\
\hline $\begin{array}{l}\text { Postal addres } \\
\text { Department o } \\
\text { Microbiology } \\
\text { Parasitology, } \\
\text { Medicine, Uni } \\
\text { Lagos, PMB } 12\end{array}$ & $\begin{array}{l}\text { f Medical } \\
\text { and } \\
\text { ollege of } \\
\text { versity of } \\
003, \text { Nigeria }\end{array}$ \\
\hline $\begin{array}{l}\text { Dates: } \\
\text { Received: } 28 \\
\text { Accepted: } 06 \\
\text { Published: } 06\end{array}$ & $\begin{array}{l}\text { Jov. } 2012 \\
\text { Vov. } 2013 \\
\text { Aug. } 2014\end{array}$ \\
\hline $\begin{array}{l}\text { How to cite th } \\
\text { Oladele RO, Ba } \\
\text { MA, Oduyebo } \\
\text { M. Candidaem } \\
\text { hospital in Nig } \\
\text { Lab Med. } 201 \\
\text { \#89, } 5 \text { pages. } \\
\text { org/10.4102/a }\end{array}$ & $\begin{array}{l}\text { is article: } \\
\text { kare RA, Petrou } \\
\text { OO, Richardson } \\
\text { ia in a tertiary } \\
\text { eria. Afr J } \\
\text {;3(1), Art. } \\
\text { ttp://dx.doi. } \\
\text { jlm.v3i1.89 }\end{array}$ \\
\hline $\begin{array}{l}\text { Copyright: } \\
\text { (C) 2014. The A } \\
\text { Licensee: AOS } \\
\text { OpenJournals } \\
\text { is licensed unc } \\
\text { Creative Comr } \\
\text { Attribution Lic }\end{array}$ & $\begin{array}{l}\text { IS } \\
\text { Ihis work } \\
\text { ler the } \\
\text { nons } \\
\text { ense. }\end{array}$ \\
\hline 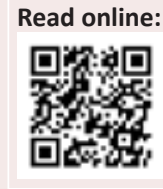 & $\begin{array}{l}\text { Scan this QR } \\
\text { code with your } \\
\text { smart phone or } \\
\text { mobile device } \\
\text { to read online. }\end{array}$ \\
\hline
\end{tabular}

Background: Candidaemia is a widely-studied and reviewed topic in the developed world; however, there is a dearth of information on nosocomial candidaemia in Nigeria, despite the increasing use of more invasive therapeutic modalities, immunosuppressive agents and increasing incidence of immunosuppression as a result of malignancies and HIV.

Objectives: To determine the hospital-based frequency of candidaemia in a tertiary hospital in Ibadan, Nigeria.

Method: This was a prospective descriptive study which included 230 immunosuppressed patients. All isolates were identified to the species level using both conventional and automated methods. Thereafter, all Candida species isolated were tested for antifungal susceptibility using the broth microdilution method.

Results: Candidaemia occurred in $12(5.21 \%)$ of the 230 study patients, with C. tropicalis accounting for $50 \%$ of the infections. Four patients (33.3\%) presented with C. parapsilosis, one $(8.3 \%)$ with C. albicans and one $(8.3 \%)$ with a mixed infection of $C$. albicans and C. tropicalis. All 12 isolates were sensitive to fluconazole (minimal inhibitory concentration $<8 \mathrm{mg} / \mathrm{mL}$ ). Univariate analysis revealed that old age, multiple surgeries and long-term hospitalisation were significant contributing factors for the occurrence of candidaemia. Eleven $(91.7 \%)$ of the 12 patients with candidaemia had Candida colonisation of other sterile sites including the bladder, peritoneum and trachea. Furthermore, bivariate analysis revealed that mucositis $(p=0.019)$ and diarrhoea $(p=0.017)$ were significantly associated with an increased risk of candidaemia. The crude mortality rate of candidaemia was $91.7 \%$.

Conclusion: This study highlights the significance of nosocomial candidaemia and the need for proactive laboratory investigation and clinical management of this life-threatening disease.

\section{Introduction}

Since the 1980s, Candida infections have become a growing problem..$^{1,2,3,4}$ Martin et al. reported a 207\% increase in incidence between 1979 and 2000 in the United States. ${ }^{5}$ Morbidity rates in immunocompromised patients are as high as 50\%. ${ }^{6,7}$ Patients with underlying clinical conditions, such as haematological malignancies, long-term intensive care unit (ICU) stays and prematurity, are at high risk for candidaemia. Independent risk factors for infection include treatment with broad-spectrum antibacterial agents, immunosuppressive therapy and/or parenteral nutrition; prior haemodialysis; and having implanted prosthetic devices. ${ }^{8,9,10,11,12}$

Candidaemia poses a complex clinical puzzle. Firstly, blood culture, the gold standard for diagnosis and treatment of candidaemia, is positive in less than $50 \%$ of infected patients and takes several days for a diagnosis. ${ }^{13}$ Second, trends in incidence and species distribution differ between geographical zones and healthcare facilities. ${ }^{14}$ Thirdly, some species of Candida are resistant to fluconazole. Without rapid diagnosis and treatment, the consequences are clear: a $20 \%$ increase in mortality was found in cases where antifungal therapy was delayed for more than 12 hours. ${ }^{15,16}$

As there is insufficient data on nosocomial candidaemia in Nigeria, we conducted a prospective study to establish the frequency of candidaemia, predisposing factors and the susceptibility of Candida spp. to fluconazole.

\section{Research method and design}

Conducted from 01 September 2008 to 30 August 2009 at University College Hospital, a 960bed, tertiary referral centre in Ibadan, Nigeria, this study enrolled 230 immunosuppressed patients who had been admitted at least 10 days prior to the start of the study and had persistent 
pyrexia (temperature $>38{ }^{\circ} \mathrm{C}$ ). Study subjects included patients presenting with haematological malignancies; ICU patients; very low birth weight (VLBW) premature neonates (temperature $>38^{\circ} \mathrm{C}$ or $<35^{\circ} \mathrm{C}$ ); patients who had undergone multiple abdominal surgical procedures during their current admission; diabetic patients with persistent pyrexia; and HIV patients. The patients' underlying diseases were classified broadly, as can be seen in Table 1. Exclusion criteria included non-consenting patients, patients without clinical signs of infection and patients already receiving empirical antifungal therapy. Probability proportionate to size was used to estimate the number of patients selected per targeted study population group. ${ }^{17}$

Participation in the study was voluntary and, after receiving written consent from the patients or their immediate relatives, the investigators explained the study in both English and Yoruba and then administered a semi-structured questionnaire, adapted from a European Confederation of Medical Mycology Intensive Care Unit (ECMM ICU) form. The questionnaire was divided into three sections: Socio-demographic Data; Medical and Surgical History (based on known risk factors for candidaemia); and Laboratory Findings.

Candidaemia was defined as being the isolation of Candida species from at least one positive blood culture sample in patients with clinical signs of bloodstream infection. Two venous blood samples of five $\mathrm{mL}$ each were collected from each patient. Ten millilitres of blood was added to each BACTEC blood culture bottle and incubated at $37{ }^{\circ} \mathrm{C}$ using a BACTEC 9050 blood culture system (Becton Dickinson, Inc., Sparks, MD, USA), an automated system that contains antibiotic-absolving resins, allowing for the culturing of blood from patients on antibiotics without discontinuing treatment. Additional advantages of this system are its rapid turnaround time and increased yield compared with the conventional, manual blood culture system. Positive samples were examined microscopically using direct gram staining; those showing yeast were cultured onto Sabouraud's dextrose agar (Oxoid, UK) and CHROMagar Candida (CHROMagar, France). The germ tube test was used for presumptive diagnosis of $C$. albicans, but all isolates were identified to the species level using API 20C AUX and/or ID 32C automated strip detection (BioMerieux Vitek, Inc., St Louis, MO, USA).

Susceptibility testing to fluconazole was performed using the broth microdilution method in accordance with the Clinical and Laboratory Standards Institute (CLSI) recommendations (M27-A2). ${ }^{18}$ Stock inocula were prepared by adding $24-48$-hourold test Candida to Roswell Park Memorial Institute (RPMI) broth and adjusting to a $0.5 \mathrm{McF}$ arland standard. The stock inocula were diluted 1:1000 and $100 \mu \mathrm{L}$ of each was added to two-fold $100 \mu \mathrm{L}$ dilutions (ranging from 0.12 to $64 \mu \mathrm{g} / \mathrm{mL}$ ) of fluconazole on the microtitre plate as well as to a drug-free medium. After incubating the microtitre plates at $35{ }^{\circ} \mathrm{C}$ for 24-48 hours, the amount of growth in a well containing the antifungal agent was compared with the amount of growth in an antifungal-free, growth-control well. The minimum inhibitory concentration (MIC) was the lowest concentration of antifungal agent that visibly inhibited $50 \%$ growth of the organism. Isolates with an $\mathrm{MIC}<8 \mathrm{mg} / \mathrm{mL}$ were considered to be susceptible to fluconazole; isolates with an MIC $>64 \mathrm{mg} / \mathrm{mL}$ were resistant. ${ }^{18}$ Those with an MIC from $16-32 \mathrm{mg} / \mathrm{mL}$ were fluconazole susceptible dose-dependent (S-DD). ${ }^{18}$ Quality control was ensured by the inclusion of CLSI-recommended quality control strains Candida parapsilopsis ATCC 22019 (MIC range 2-8 mg/mL) and Candida krusei ATCC 6258 (MIC range $16-64 \mathrm{mg} / \mathrm{mL}$ ).

Quantitative data from the questionnaire were entered into Microsoft Excel 2003 (v11.0) (Microsoft, Redmond, WA) and SPSS 15.0 for Windows (SPSS Inc., Chicago, 2006) was used for the analysis. The univariate analysis used descriptive statistics and tables, including frequency distribution; and the bivariate analysis used the chi-square test with statistical significance set at $p<0.05$.

\section{Results}

Of the 230 study patients, the median age was 18 years, with $27.5 \%(n=63)$ being less than one year old and $10.9 \%(n=25)$ older than 60 . The male-to-female ratio was 1.12:1. All patients were admitted for hospitalisation: $39.7 \%(n=89)$ for $11-20$ days and $17.8 \%(n=42)$ for more than 30 days (Table 1$)$.

Seven percent $(n=16)$ of the patients underwent more than one operation (Table 2). Most of the study population (97.4\%; $n=224)$ were treated with broad-spectrum antibiotics; $45.7 \%$ $(n=105)$ of these received 11-20 days of different combination of broad-spectrum antibiotics. The median duration of antibiotic use was 15.5 days, with only $11.7 \%(n=27)$ of

TABLE 1: Demographic characteristics of patients studied and underlying diseases.

\begin{tabular}{|c|c|c|}
\hline Demographic characteristics & Frequency & Percentage (\%) \\
\hline \multicolumn{3}{|l|}{ Age in years } \\
\hline$<1$ & 63 & 27.5 \\
\hline $1-5$ & 23 & 10.0 \\
\hline $6-20$ & 31 & 13.5 \\
\hline $21-40$ & 42 & 18.3 \\
\hline $41-60$ & 45 & 19.7 \\
\hline$>60$ & 25 & 10.9 \\
\hline \multicolumn{3}{|l|}{ Sex } \\
\hline Male & 125 & 55.3 \\
\hline Female & 101 & 44.7 \\
\hline \multicolumn{3}{|l|}{ Number of days of admission } \\
\hline $0-10$ & 64 & 28.3 \\
\hline $11-20$ & 89 & 39.7 \\
\hline $21-30$ & 35 & 14.2 \\
\hline $30+$ & 42 & 17.8 \\
\hline \multicolumn{3}{|l|}{ Underlying disease } \\
\hline Systemic infection & 50 & 21.7 \\
\hline Sepsis & 35 & 15.2 \\
\hline Solid tumours & 30 & 13.0 \\
\hline Haematological malignancy & 25 & 10.9 \\
\hline Very low birth weight & 25 & 10.9 \\
\hline HIV & 24 & 10.4 \\
\hline Renal diseases & 19 & 8.3 \\
\hline Diabetes mellitus & 12 & 5.2 \\
\hline Severe burns & 5 & 2.2 \\
\hline Severe head injury & 5 & 2.2 \\
\hline
\end{tabular}


patients receiving antibiotic treatment for more than 21 days (Table 2). Most patients had at least one invasive procedure during their admission, with $92.2 \%(n=212)$ undergoing intravenous cannulation and $8.7 \%(n=7)$ undergoing venous cutdown (Table 2). Other treatments used in this population included antifungal therapy for non-invasive candidiasis, anti-cancer chemotherapy, radiotherapy, steroids and highlyactive antiretroviral therapy (HAART).

The distribution pattern of isolates from blood culture samples showed that Staphylococcus aureus $(42.9 \% ; n=30)$ and Klebsiella spp. $(20.0 \% ; n=14)$ were the most common pathogens, followed by Candida spp. $(17.1 \% ; n=12)$ (Figure 1$)$. Of the enrolled patients, $12(5.2 \%)$ had candidaemia. C. tropicalis ( $n=6 ; 50 \%$ ) was the most frequently-identified Candida spp. (Figure 2). Based on CHROMagar Candida phenotypes, one patient had a polymicrobial infection with both $C$. albicans and C. tropicalis. Candida spp. was also isolated from non-venous, invasive sites in $11(91.7 \%)$ of the 12 patients (Figure 3). All Candida spp. isolates were susceptible to fluconazole (MIC $<8 \mathrm{mg} / \mathrm{mL}$ ). In addition, the API 20C AUX and ID 32C identification of the Candida spp. were in concordance with one another.

Of the 12 (5.2\%) patients with candidaemia in this study, age $(p=0.8)$ and sex $(p=0.16)$ distributions were not of statistical significance. These patients' underlying diseases included solid tumours, diabetes, HIV, infective endocarditis, haematological malignancy, VLBW, severe head injury and sepsis. There was no significant relationship $(p=0.18)$ between underlying disease and the various Candida spp. detected. Using chi-square analysis, diarrhoea $(p=0.017)$ and oral thrush (mucositis) ( $p=0.019)$ were the only statisticallysignificant symptoms (Table 3 ). The crude mortality rate was $91.7 \%$ (11 out of 12 patients).

\section{Ethical considerations}

Ethical approval for the study was obtained from the National Health Research Ethics Committee (NHREC/ 05/01/2008a) and, in keeping with ethical procedures, the patients or their immediate relatives provided informed written consent.

TABLE 2: Treatment history of patients in the study.

\begin{tabular}{lcc}
\hline Clinical Characteristics & Frequency & Percentage (\%) \\
\hline Number of surgical operations & 165 & 71.7 \\
None & 49 & 21.3 \\
1 & 16 & 7.0 \\
$>1$ & & \\
Duration of broad spectrum antibiotic therapy & 92 & 42.6 \\
1-10 days & 105 & 45.7 \\
11-20 days & 27 & 11.7 \\
21-40 days & & \\
Invasive procedures & 212 & 92.2 \\
Intravenous cannulation & 143 & 62.2 \\
Nasogastric tube passage & 118 & 51.8 \\
Urinary catheterisation & 20 & 13.6 \\
Tracheostomy & 7 & 8.7 \\
Venous cutdown & & \\
\hline
\end{tabular}

\section{Potential benefits and hazards}

The sample collection is a minimum risk procedure (venipuncture under standard precautions). Benefits to the participants included free blood culture and feedback of results to the managing clinicians.

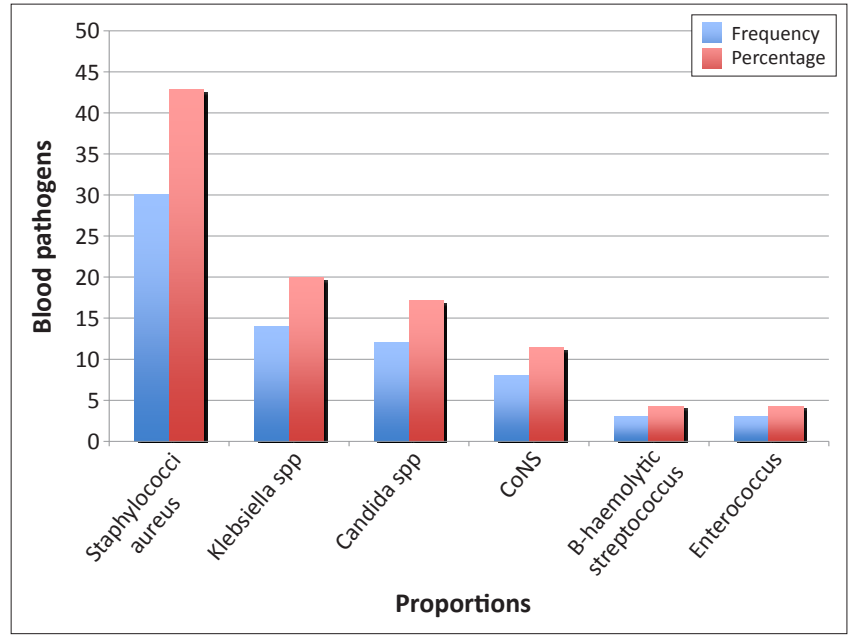

CoNS, Coagulase-negative staphylococci.

FIGURE 1: Bar chart showing distribution of pathogens causing bloodstream infections.

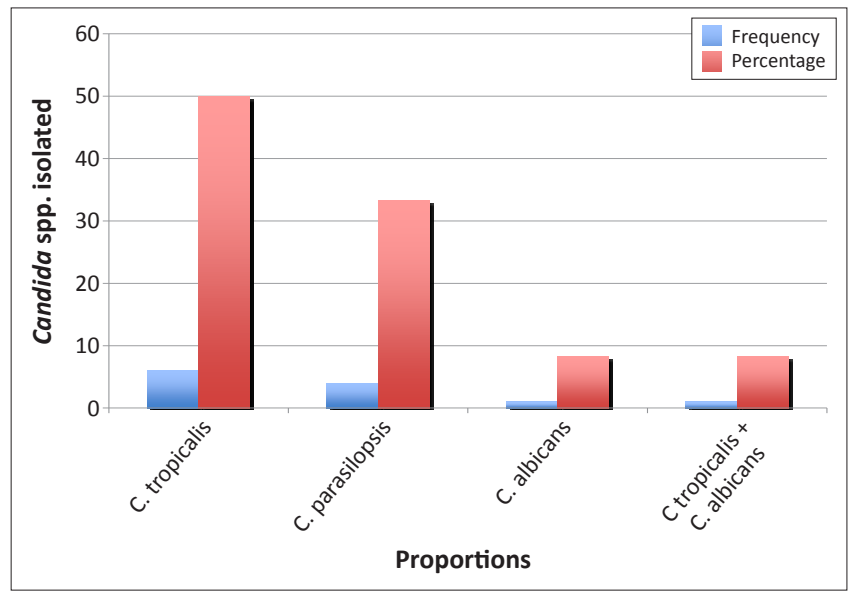

FIGURE 2: Bar chart showing distribution of Candida spp. causing bloodstream infections.

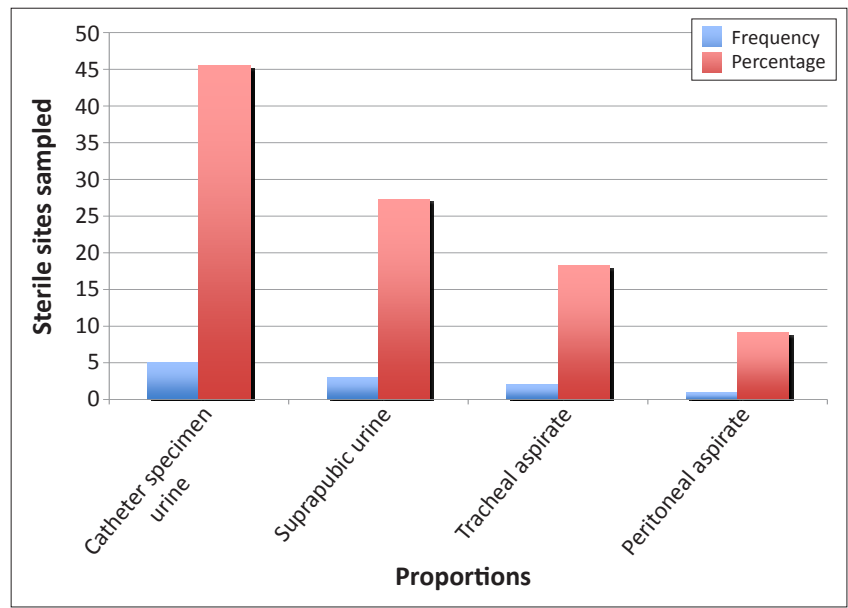

FIGURE 3: Bar chart showing distribution of Candida spp. isolated from other sterile sites. 
TABLE 3: Association of symptoms of immunosuppression in patients who developed candidaemia.

\begin{tabular}{|c|c|c|c|c|c|c|c|}
\hline \multirow[t]{2}{*}{ Signs } & \multirow[t]{2}{*}{ Symptoms } & \multicolumn{2}{|c|}{$\begin{array}{l}\text { Candida } \\
\text { positive }\end{array}$} & \multicolumn{2}{|c|}{$\begin{array}{l}\text { Candida } \\
\text { negative }\end{array}$} & \multirow[t]{2}{*}{$\begin{array}{c}\text { Chi-square } \\
\text { value }\end{array}$} & \multirow[t]{2}{*}{$p$-value } \\
\hline & & $n$ & $\%$ & $n$ & $\%$ & & \\
\hline \multirow{2}{*}{ Diarrhoea } & Yes & 4 & 14.8 & 23 & 14.8 & 5.698 & 0.017 \\
\hline & No & 8 & 3.9 & 195 & 3.9 & & \\
\hline \multirow[t]{2}{*}{ Fever } & Yes & 9 & 4.6 & 186 & 95.4 & 0.936 & 0.333 \\
\hline & No & 3 & 8.6 & 32 & 91.4 & & \\
\hline \multirow[t]{2}{*}{ Lethargy } & Yes & 8 & 6.6 & 113 & 93.4 & 1.004 & 0.316 \\
\hline & No & 4 & 3.7 & 105 & 96.3 & & \\
\hline \multirow[t]{2}{*}{ Weight loss } & Yes & 7 & 5.4 & 123 & 94.6 & 0.017 & 0.897 \\
\hline & No & 5 & 5.0 & 95 & 95.0 & & \\
\hline \multirow{2}{*}{$\begin{array}{l}\text { Loss of } \\
\text { appetite }\end{array}$} & Yes & 4 & 4.9 & 78 & 95.1 & 0.030 & 0.863 \\
\hline & No & 8 & 5.4 & 140 & 94.6 & & \\
\hline \multirow[t]{2}{*}{ Skin rashes } & Yes & 0 & 0.0 & 19 & 100.0 & 1.140 & 0.286 \\
\hline & No & 12 & 5.7 & 199 & 94.3 & & \\
\hline \multirow{2}{*}{$\begin{array}{l}\text { Boils/ } \\
\text { carbuncles }\end{array}$} & Yes & 0 & 0.0 & 7 & 100.0 & 0.397 & 0.528 \\
\hline & No & 12 & 5.4 & 211 & 94.6 & & \\
\hline \multirow[t]{2}{*}{ Oral thrush } & Yes & 5 & 12.8 & 34 & 87.2 & 5.490 & 0.019 \\
\hline & No & 7 & 3.7 & 184 & 96.3 & & \\
\hline \multirow[t]{2}{*}{ Sore throat } & Yes & 0 & 0.0 & 5 & 100.0 & 0.281 & 0.596 \\
\hline & No & 12 & 5.3 & 213 & 94.7 & & \\
\hline \multirow[t]{2}{*}{ Cough } & Yes & 2 & 6.9 & 27 & 93.1 & 0.189 & 0.664 \\
\hline & No & 10 & 5.0 & 191 & 95.0 & & \\
\hline \multirow[t]{2}{*}{ Hypothermia } & Yes & 1 & 2.6 & 34 & 97.4 & 0.669 & 0.414 \\
\hline & No & 11 & 5.8 & 180 & 94.2 & & \\
\hline \multirow{2}{*}{$\begin{array}{l}\text { Feed } \\
\text { intolerance }\end{array}$} & Yes & 0 & 0.0 & 2 & 100.0 & 0.111 & 0.739 \\
\hline & No & 12 & 5.3 & 216 & 94.7 & & \\
\hline \multirow{2}{*}{$\begin{array}{l}\text { Loss of } \\
\text { consciousness }\end{array}$} & Yes & 5 & 7.8 & 59 & 92.2 & 1.208 & 0.272 \\
\hline & No & 7 & 4.2 & 159 & 95.8 & & \\
\hline \multirow[t]{2}{*}{ Vomiting } & Yes & 1 & 4.2 & 23 & 95.8 & 0.060 & 0.807 \\
\hline & No & 11 & 5.3 & 195 & 94.7 & & \\
\hline
\end{tabular}

\section{Trustworthiness}

Confidentiality was ensured by the identification of participants with code numbers. Other personal details of the participants were kept in safe keeping with the lead researcher for 5 years in a secured file.

\section{Discussion}

Candidaemia is a nosocomial infection commonly seen in critically-ill patients and those with haematological malignancies. ${ }^{1,2,4,6,19}$ In this study, Candida spp. ranked third among pathogens causing blood stream infections (BSIs) in hospitalised patients admitted to the study centre. Findings from North American and European surveillance programmes of hospital-acquired infections showed that isolates of Candida spp. were the fourth most common cause, accounting for $8 \%-10 \%$ of nosocomial BSIs. ${ }^{19}$ This difference could exist because all of the participants in this study were immunosuppressed; not all presented with BSIs; and the developed world has established protocols and guidelines for the diagnosis, management and prevention of invasive fungal infections.

The hospital-based frequency of candidaemia in this study was $5.2 \%$, which could possibly be a result of Nigeria's progressive changes in the medical and surgical management of patients over the last five years. These improvements have reduced the vulnerability of critically-ill patients to haematogenous dissemination of Candida spp. whereas previously, bacterial and/or viral infections often resulted in fatalities. Conversely, antifungal drugs are not administered routinely, either empirically or as prophylaxis, in the management of high-risk patients in Nigeria, which could possibly explain the high mortality rates from candidaemia.

Several risk factors for candidaemia have been shown in previous studies and confirmed in this study. In this study, patients under the age of one $(n=63)$ accounted for $27.5 \%$ of the study population and $25 \%$ of patients with candidaemia. This is consistent with findings by Saiman et al. which showed that infants, especially premature, VLBW babies, have a higher risk of candidaemia because of their immature immune systems and frequent intubation. ${ }^{20}$ Patients over the age of $60(n=25)$ accounted for $10.9 \%$ of the studied population and $16.7 \%$ of the cases of candidaemia, which is relatively high, but not of statistical significance; however, Schelenz found that old age was an independent risk factor for candidaemia. ${ }^{21}$

Two of the patients had infective endocarditis, one of whom had undergone cardiac surgery, a high-risk factor for fungal endocarditis, with an infection rate of $0.23 \%-1.0 \% .^{22,23}$ Another known risk factor for candidaemia is long-term hospital stays, especially in ICU settings. ${ }^{22}$ There was a correlation between length of hospital stay and frequency of candidaemia, further confirming the nosocomial source of the infection and that prolonged hospital stays are risk factors. . $, 3,19^{2}$

Broad-spectrum antibiotic use is a major risk factor for the development of candidaemia because these medications eliminate the bacterial gut flora and encourage the overgrowth and dissemination of gastrointestinal fungal commensals. ${ }^{19,21}$ Almost all of the enrolled patients with candidaemia were taking several antibiotics, for a median period of 15.5 days.

Most patients had intravenous lines in situ, but only $13.6 \%$ $(n=7)$ underwent intravenous cutdown (femoral vein). 11 of the 12 patients with candidaemia had the same Candida spp. isolated from other sites. Symptoms associated with candidaemia were mucositis $(p=0.019)$ and diarrhoea $(p=0.017)$. These findings are consistent with those of other reports showing mucosal colonisation to be an independent risk factor for candidaemia,;1,24 however, there are no previous studies citing any relationship between candidaemia and diarrhoea.

The high proportion of C. tropicalis (50\%) reported here is consistent with a study in India by Verma et al. where the proportion was $46 \% .^{25}$ The crude mortality rate in our study was $91.7 \%$ (11 out of 12 patients) compared with the $35 \%-75 \%$ crude mortality rates reported in other studies. ${ }^{23}$ This could be attributed to small sample sizes, as well as to the fact that the clinicians at the study site did not administer antifungal drugs routinely, either on an empirical or a prophylactic basis, for the management or prevention of candidaemia. Clinicians may not consider candidaemia as a cause of infection because of limited training in nosocomial diseases, the absence of knowledge of disease prevalence (NCBI 
Pubmed searches reveal few publications in the field from Nigeria) and the lack of an established infrastructure for high-quality laboratory testing.

\section{Limitations of the study}

Limitations of this study include the small sample size and generalised study population.

\section{Conclusion}

This study highlights the clinical significance of nosocomial candidaemia and the need for proactive investigation for possible invasive candidiasis. This is particularly needed in Nigeria where patients have to pay for every laboratory investigation carried out in the hospital; as a result, clinicians cannot proactively and/or repeatedly request tests or cultures. This study highlights the need for affordable laboratory tests and an improved understanding of the dangers of untreated candidaemia. Finally, improved communication and collaboration between clinicians and clinical microbiologists is essential for the development of measures to control the emerging threat of nosocomial candidaemia.

\section{Acknowledgements}

The authors would like to acknowledge Prof. Marianna Viviani for her contribution with the ECCM ICU form and her advice on specimen storage and transportation, as well as Drs Olubunmi Olubanwo and Victor Uwadike for their help in sample collection and data collation.

\section{Competing interests}

Prof. Malcolm Richardson has received research funding and speaker fees from Gilead Science, Pfizer, MSD and Astellas. The other authors declare that they have no financial or personal relationship(s) that may have inappropriately influenced them in writing this article.

\section{Authors' contributions}

R.O.O. (University College Hospital, Nigeria) was involved in the conception and design of the study, as well as with the acquisition, analysis and interpretation of the data. She also wrote the article. R.A.B. (University College Hospital, Nigeria) was involved in the conception and design of the study, as well as the write up. M.R. (University of Manchester) had substantial involvement in the revision of the article and performed the expert review prior to submission. O.O.O. (University of Lagos, Nigeria) was involved in the conception of the article, as well as the data collection and analysis. M.A.P. (Hammersmith Hospital) was involved in the design of the study, as well as in laboratory analysis of the isolates and write up of the manuscript.

\section{References}

1. Wisplinghoff $\mathrm{H}$, Bischoff T, Tallent SM, et al. Nosocomial bloodstream infections in US hospitals: analysis of 24,179 cases from a prospective nationwide surveillance study. Clin infect Dis. 2004;39(3):309-317. http://dx.doi.org/10.1086/421946

2. Bassetti M, Righi E, Costa $A$, et al. Epidemiology trends in nosocomial candidemia in intensive care. BMC Infect Dis. 2006;6:21. http://dx.doi.org/10.1186/1471-2334-6-21

3. Davis SL, Vazquez JA, McKinnon PS. Epidemiology, risk factors, and outcomes of Candida albicans versus non-albicans candidemia in non-neutropenic patients. Ann Pharmacother. 2007;41(4):568-573. http://dx.doi.org/10.1345/aph.1H516

4. Pfaller MA, Diekema DJ, Jones RN, et al. International surveillance of bloodstream infections due to Candida species: frequency of occurrence and in vitro susceptibilities to fluconazole, ravuconazole, and voriconazole of isolates collected from 1997 to fluconazole, ravuconazole, and voriconazole of isolates collected from 1997 2001;39(9):3254-3259. http://dx.doi.org/10.1128/JCM.39.9.3254-3259.2001

5. Martin GS, Mannino DM, Eaton S, et al. Epidemiology of sepsis in the United States from 1979 through 2000. N Engl J Med. 2003;348(16):1546-1554. http://dx.doi. org/10.1056/NEJMoa022139

6. Pappas PG, Kauffman CA, Andes D, et al. Clinical practice guidelines for the management of candidiasis: 2009 update by Infectious Diseases Society of America. Clin Infect Dis. 2009;48(5):503-535. http://dx.doi.org/10.1086/596757

7. Gudlaugsson $\mathrm{O}$, Gillespie $\mathrm{S}$, Lee $\mathrm{K}$, et al. Attributable mortality of nosocomial candidemia, revisited. Clin Infect Dis. 2003;37(9):1172-1177. http://dx.doi.org/ 10.1086/378745

8. Chen LY, Liao SY, Kuo SC, et al. Changes in the incidence of candidaemia during 2000-2008 in a tertiary medical centre in Northern Taiwan. J Hosp Infect. 2011;78 (1):50-53. http://dx.doi.org/10.1016/j.jhin.2010.12.007

9. Horn DL, Neofytos D, Anaissie EJ, et al. Epidemiology and outcomes of candidemia in 2019 patients: data from the prospective antifungal therapy alliance registry. Clin Infect Dis. 2009;48(12):1695-1703. http://dx.doi.org/10.1086/599039

10. Bedini A, Venturelli $C$, Mussini $C$, et al. Epidemiology of candidaemia and antifungal susceptibility patterns in an Italian tertiary-care hospital. Clin Microbiol Infect. 2006;12(1):75-80. http://dx.doi.org/10.1111/j.1469-0691.2005.01310.x

11. Pappas PG, Rex JH, Lee J, et al. A prospective observational study of candidemia: epidemiology, therapy, and influences on mortality in hospitalized adult and pediatric patients. Clin Infect Dis. 2003;37(5):634-643. http://dx.doi.org/10.1086/376906

12. Trick WE, Fridkin SK, Edwards JR, et al. Secular trend of hospital-acquired candidemia among intensive care unit patients in the United States during 1989-1999. Clin Infect Dis. 2002;35(5):627-630. http://dx.doi.org/10.1086/342300

13. Hsu JL, Ruoss SJ, Bower ND, et al. Diagnosing invasive fungal disease in critically ill patients. Crit Rev Microbiol. 2011;37(4):277-312. http://dx.doi.org/10.3109/1 040841X.2011.581223

14. Hobson RP. The global epidemiology of invasive Candida infections - is the tide turning? J Hosp Infect. 2003;55(3):159-168. http://dx.doi.org/10.1016/j.jhin. 2003.08.012

15. Guery BP, Arendrup MC, Auzinger G, et al. Management of invasive candidiasis and candidemia in adult non-neutropenic intensive care unit patients: Part I. Epidemiology and diagnosis. Intensive Care Med. 2009;35(1):55-62. http://dx.doi. org/10.1007/s00134-008-1338-7

16. Morrell M, Fraser VJ, Kollef MH. Delaying the empiric treatment of Candida bloodstream infection until positive blood culture results are obtained: a potential risk factor for hospital mortality. Antimicrob Agents Chemother. 2005;49(9):36403645. http://dx.doi.org/10.1128/AAC.49.9.3640-3645.2005

17. Desu MM, Raghavarao D. Sample size methodology. Boston: Academic Press; 1990.

18. Clinical and Laboratory Standards Institute. Reference method for broth dilution antifungal susceptibility testing of yeasts; approved standard - second edition. Vol 22, doc M27-A2. Wayne, PA: Clinical and Laboratory Standards Institute; 2002.

19. Edmond MB, Wallace SE, McClish DK, et al. Nosocomial bloodstream infections in United States hospital: a three-year analysis. Clin Infect Dis. 1999;29(2):239-244. http://dx.doi.org/10.1086/520192

20. Saiman L, Ludington E, Pfaller $M$, et al. Risk factors for candidemia in neonatal intensive care unit patients. The National Epidemiology of Mycosis Survey study group. Pediatr Infect Dis J. 2000;19(4):319-324. http://dx.doi.org/10.1097/ 00006454-200004000-00011

21. Schelenz S. Management of candidiasis in the intensive care unit. J Antimicrob Chemother. 2008;(61 suppl 1):i31-i34. http://dx.doi.org/10.1093/jac/dkm430

22. Aspesberro $F$, Beghetti $M$, Oberhänsli I, et al. Fungal endocarditis in critically ill children. Eur J Pediatr. 1999;158(4):275-280. http://dx.doi.org/10.1007/ s004310051071

23. Dean DA, Burchard KW. Fungal infection in surgical patients. Am J Surg. 1996;171(3): 374-382. http://dx.doi.org/10.1016/S0002-9610(97)89647-X

24. Jordà-Marcos $R$, Alvarez-Lerma $F$, Jurado $M$, et al. Risk factors for candidaemia in critically ill patients: a prospective surveillance study. Mycoses. 2007;50(4):302-310. http://dx.doi.org/10.1111/j.1439-0507.2007.01366.x

25. Verma AK, Prasad KN, Singh M, et al. Candidaemia in patients of a tertiary health care hospital from north India. Indian J Med Res. 2003;117:122-128. 